out the hope that it may soon be possible for the archæologist to discern the long awaited Arthurian archæology of Britain. Though Vortigern, Aurelius Ambrosianus, and King Arthur mean much to the historian, archæologically they and their subjects are almost unknown. The lost archæology of the Briton has to be reconstructed from material found in the graves of his conquerors. Investigation of the chronological position of such material as the famous 'Kingston' brooch shows that it is more likely to be British than Jutish, as it has been regarded. There is a definite probability of some progress in the task of sorting out minor Arthurian antiquities from the 'Anglo-Saxon' cases of the museums.

\title{
Rimu or New Zealand Red-Pine
}

$I^{\mathrm{N}}$ view of the fact that the possibility of obtaining supplies of soft woods from the Empire is so much in the forefront at the present day, a leaflet by W. C. Ward on the "Properties and Uses of Rimu" (N.Z. For. Service, Leaflet, No. 17, Nov. 1931) merits consideration. The author states that rimu (Dacry. dium cupressinum) supplies rank as the most important soft wood in New Zealand. It is milled and marketed in every timber-producing district in the country, and is the principal building timber in the Dominion. It is employed in almost every local woodusing industry, and in many is the chief timber used. At the present time, practically the whole of the rimu produced is consumed locally, less than 3 per cent being exported. The quantity milled annually exceeds that of all other species combined, and during the year ending March 31, 1930, totalled 159,000,000 ft. Board Measure (B.M.), or 58 per cent of the total timber production of the Dominion. In 1920-1930 the annual cut of the species exceeded 140,000,000 ft. B.M., the peak production of $195,000,000 \mathrm{ft}$. B.M. in 1926 representing 55 per cent of the total timber produced that year. That the fellings are exceeding the annual increment or possibility is exemplified by the statement that a few years ago Auckland supplied a far larger proportion of the total cut than any of the other districts, but its accessible supplies have now dwindled, and Westland has taken the lead and is said to be likely to supply an increasing percentage in future years.

The first detailed statistics on the export of rimu were collected in 1913 , when $8,500,000 \mathrm{ft}$. B.M. were exported. In the War years the trade increased, and by 1918 the total exports had reached $30,000,000 \mathrm{ft}$. B.M. This was due to the difficulty in obtaining supplies of North American and Scandinavian timber during the War years. With the drop in price of the foreign species at the end of the War, and low ocean freights, it was possible to land the foreign material cheaper in Australia than rimu. The exports of the latter to Australia had fallen to $4,000,000 \mathrm{ft}$. B.M. in
1925, and have remained at that figure ever since. Recent customs duties on foreign timber in Australia now permit rimu to compete successfully once more, and a recent survey has shown that $20,000,000 \mathrm{ft}$. B.M. of rimu could be used in Australia annually.

The leaflet is written from the marketing and manufacturing point of view. It is to be hoped that the Forest Department will bear in mind the great value to the country of this fine timber, and will take steps to see that its regeneration is undertaken, in order to perpetuate supplies.

The rimu is a fine forest tree, the height in the average commercial stand varying from $60 \mathrm{ft}$. to $120 \mathrm{ft}$. When mature, its trunk is long, straight, unbranched, and with little taper, carrying a compara. tively open and irregular crown. From the remarkable weeping habit of its foliage it is the most easily recognised and best known of all New Zealand trees. The commercial bole usually varies from $40 \mathrm{ft}$. to $80 \mathrm{ft}$. in length. Its diameter, breast height, in mature stands varies from $2 \mathrm{ft}$. to $4 \mathrm{ft}$., although it is said that many of the trees at present converted range below the lower limit. In other words, as is invariably the case when primeval forests are lumbered, immature trees are being felled along with the mature ones. Occasionally trees up to $8 \mathrm{ft}$. diameter are encountered and milled. It might be suggested that a few stands of these fine old trees should be selected by Government and reserved to show future generations what the New Zealand soil is capable of producing.

Although the tree grows on flat, but not marshy, land, it favours undulating localities and hillsides, being found at all altitudes from sea-level up to $2500 \mathrm{ft}$. With the exception of the pure beech (Nothofagus) stands, rimu occurs in every major type of forest growth, and in the North Island it is an occasional associate of the kauri.

Mr. Ward gives interesting details on manufacture, seasoning, grading, the properties of the wood and durability, and adds notes on its utilisation by various industries.

\section{Winter Climate of Greenland}

TN a paper read to the Royal Geographical Society on April 18, by Mr. S. T. A. Mirrlees, new light is thrown on the winter climate of the interior of southern Greenland. Mr. Mirrlees pointed out that nearly all our knowledge of the climate of this region is based upon observations made on summer sledge journeys, supplemented by the observations made throughout the year at the various coast stations of the Danish Meteorological Service. Greenland lies to the north of the region of the world's most persistent cyclonic activity, but-if we accept as accurate the distribution of high and low pressure shown on the daily charts of the British Meteorological Office and similar older publications, such as those of the Danish Admiralty-is at all seasons liable to be invaded by the cyclonic depressions of the North Atlantic.

In a series of observations made every three hours between Sept. 8, 1930, and April 26, 1931, at about lat. $67^{\circ}$ N., long. $42^{\circ}$ W., at a height of about
$8250 \mathrm{ft}$. , by the British Arctic Air Route Expedition, his hypothesis is confirmed. The direct influence of the Atlantic depressions on the weather was found normally to be small, as is shown by the low figures for the monthly mean proportion of the sky covered by cloud, which varied from five-tenths in September to three-tenths in February. The mean for the whole period must therefore have been roughly comparable with the normal for the French Riviera. But there were some stormy periods and even gales, and the strongest winds showed no tendency to be more prevalent from the prevailing northerly direction of the wind than from other quarters; moreover, the characteristic changes of wind, pressure, and weather caused by the passage of the centre of a depression directly over or to the north of the place of observation were observed.

Very low temperatures had been expected, and were not wanting, for a reading of $-59^{\circ} \mathrm{F}$. was

No. 3276 , Vor. 130 ] 